\title{
Migration Labor Laws
}

\author{
Maria Pitukhina \\ Russian Science Academy, Petrozavodsk
}

\begin{abstract}
This study continues to discuss the various legislative structures associated with migrant workers 'unfree labor;' as it also continues to question as to how a set of laws and standards regarding international labor will articulate and justify this problem adequately and would then attempt to fix it. The study continually relates to the exploitative, enforced labor activities, involving slavery, debt slavery, forced labor and trading in labor. A "labor -based framework" could possibly be regarded as an empirical paradigm that takes into account the political and economic history of exploitation; emphasizes on the deterrence and social explanations for inequality and abuse rather than on the enforcement of slavery; recognizes the value of labor rights and other labor market regulatory frameworks and considers the progression of spectrum within these regards.
\end{abstract}

Keywords: Migration Labor Laws

\section{Introduction}

Largely, international stakeholders are now regarding to the international businesses being accountable for the relative treatment of the migrant labor force within their production chains, as there are many labor rights concerns and violations in contracting facilities. In specific regards to multiple countries i.e. even the developed regions, the attention of the civil society and the media has strictly risen in consideration to the conditions of migrant workers. Such problems, complications and concerns have increasingly risen because of the uncovered massive labor abuses which have placed the focus upon several corporations' agenda for the first time.

Migrant workforce is often considered to be respected as they continue to deal with a vast variety of characteristics, including: providing services at lower incomes (Prívara, 2019; Todaro, 1969), are subjected to reduced taxations; decreased risk of absenteeism, cater to the problems and complications relative to higher unemployment and willingness to operate in overtime (Mosley and Singer, 2015; Rievajova et al., 2018). However, as demonstrated by the specific violations mentioned next door, migrant workers do have improved weaknesses. Such violations generate foreign workers' particular requirements relative to domestic employees, and these are all too frequently not managed or catered across the global markets. Till present, the overall response from the businesses towards the violations faced by the migrant workforce has almost entirely been focused on risk mitigation in geographical regions (Gonzalez, 2015; Přivara and Přivarová, 2019). These reactive strategies may be unsuccessful and have no impact on global problems. In fact, policies adopted under such conditions may prove to be immensely unsustainable.

Moving on, the first aspect that this study continues to focus upon is specifically conceptual. The study questions, in the scope of foreign low-skilled workers, as to under what circumstances, legal terminology defining unfree work may be enforced concretely and regularly. This is done by the definition, examination and deconstruction of core elements in contemporary perception in unfree work. I t can be considered that the "legitimate" instances of migrant labor are distinguished by three criteria that converge: infringement of integrity, oppression and autonomy (Nica, 2015; Gröger and Zylberberg, 2016). Extreme integrity breaches may be associated with sales and other types of human objectification. Exploitation may be characterized by relative criteria based on offender judgments and specific criteria such as 
infringements of labor law. Violation of sovereignty requires human, psychological, financial and legal methods of intimidation and power.

\section{Research Methods}

\section{Methodology}

The management forms and the oppressive pressures the migrant workers continue to encounter have an effect upon immigrant workers' and their agencies. The method that is pursued within this study can be defined more effectively as resolving 'choice' uncertainty under regulations. The emphasis is on the limited choice of the migrant workforce between undesirable alternatives, a limited choice which ends in violation of autonomy and integrity.

\section{Findings}

Through the form of the usage of documents and whole proceedings, the court records are known. It starts before the decision and persists during the process and after the conclusions. It is a main option and a conceptual judgment. The background of every case involves stakeholders' representations, procedures, temporary proceedings, regular court hearings and communications and comments. Such These information shows what occurred in the trial in the civil process and after a decision. This needs an appraisal of the execution of the policies and of their responses in effect by state departments and other government actors.

\section{Literature Review}

\section{Impact of Migrant Labor on the Market}

Immigration has a highly significant effect on the labor sector, based on the consideration of the migrants' abilities, the abilities of local employees and even the local economic environment characteristics. They would therefore vary in the short and long term whether the economy and demand for labor will change to expand labor supplies. The availability of labor is influenced by globalization, because it raises the population in the case of certain sectors of the economy (Zimmermann, 2016; Ruiz and Vargas-Silva, 2015). At the same period, the market for jobs is expected to rise as migrants raise customer appetite for those products and services. This suggests that, in some industrial fields, immigration may increase the demand for established jobs, but may also produce new work (Massey et al., 1999).

The immediate short-term impact of migration on locally established workers and their salaries or occupations rely on how effectively migrants will supplement or substitute current workers' abilities, (Orrenius and Zavodny, 2015; Ruhs and VargasSilva, 2015). As foreign workers compete for current jobs, the demand for employment is projected to rise and pay reductions are likely in the short term. With respect to jobs, it affects the ability to consider the new reduced pay to raise the unemployment or inactivity of current employees. When, on the other hand, migrants ' skills are comparable to those of established employees, the efficiency of the labor force will also improve, and the wages of existing employees may improve (Sirkeci and Prívara, 2017). In general, workers employed in the low-skilled positions are likely to face more pressure from the involvement of the migrants and this may be because the skills they require become easy and quicker to learn and less specialized (Dancygier and Walter, 2015).

Furthermore, immigration will often increase the supply of workforce within the labor markets and thereby generate new employment, as well as growing labor market. That is because within the market the normally considered lump of labor would come to an end as there will be no defined number of workers. In the field of labor for migrants such as farming or the health sector, migrants can boost market demand for products and services, and companies can raise production (Hosoe, 2018; Malaeb and Wahba, 2018). Wage and job shifts must not be considered as the only way to respond towards the increase in diversity within a country considering the level of involvement of the migrants. Firstly, immigration could shift the economic balance of products and services and therefore shift the structure of the labor market's industrial and commercial structure. 


\section{Temporary Worker Programs}

Contractual migrant employees typically occupy contractual or season - based positions in foreign countries in such services. Migrants seem to be transient in these schemes, because their jobs are precarious and so they are not able to live overseas until the completion of their employment and contracts (Bird, 2018; Prívara, 2019). Many policies, such as in Austria, Germany, Mexico and Canada, make it a requirement to staff to re-entry in next season that conform with the visas to their season i.e. return after their employment expires (Sarkar, 2017; Clark, 2018; Prívara and Rievajová, 2019). Another form of program that are featured normally for migrants could be regarded as temporary workers, permanent jobs program. They are normally regarded as the most popular temporary employee services that seek to transform temporary international employees into permanent or full-year jobs (Martin, 2015; Kalleberg, 2018). Temporary employees in most situations earn 1 or multi-year job permits, although the privileges of employers and migrants to extend stays and to alter status differ considerably. Legal H-2A foreign employees in the USA in the mid-1980s, for example, may not be considered for citizenship that ended in immigration status (Alarcón, 2017; Gordon, 2016). Temporary workers in Italy may be removed from legal status by reporting them for a period of one year but do not re-register them.

Thirdly, the probationary immigrant programs can be regarded as such international workers' schemes, as their length of stay grows periodically, while offering further benefits to foreign employees (Ellermann and Gorokhovskaia, 2019; Sirkeci et al., 2018; Sirkeci et al., 2017). Most temporary employment services in Europe in the 1960s originally provided job and residency permits for one year. When employers applied for an extension of the migrant permit, the extension was typically two years and generally required a migrant to unify their family assuming the migrant could demonstrate appropriate accommodation in the country of work (Martin, 2017). The migrants usually retain immigration or relocation privileges after another two-year upgrade (five years), ensuring that it will operate in virtually all non-citizen-compliance occupations. The migrant will gain citizenship after a period of five to ten years of legal residency and jobs.

\section{Migrant Worker Ties}

International workers typically obtain visas for work and residency that bind them to a specific employer. In the case where the migrant is either laid off or fired, she / he typically loses the opportunity, after a trial period of one week to one month, to reside in the region. This "extended servitude" feature of temporary worker schemes, binds the workers in relation to a particular boss, renders them controversial with most labor unions; they contend that temporary foreign workers relying on employers to live in the country can not claim their interests efficiently (Bloch and McKay, 2015; McCollum and Findlay, 2015; Moroşanu, 2016).

Migrant employees could help defend their interests because they had freedom of travel on the workforce of the host nation, which implies, in or across the job market, they could switch from one employer to another (Prívara et al., 2019). Regional open labor markets like the EU enable this freedom of travel, allowing European nationals to migrate and obtain employment on an equal footing with local employees (with the exception of those seeking national citizenship) (Privara, 2019; Filipec and Vargová, 2019). Freedom of travel is often open to undocumented migrants because, whether the option is bound to a single boss, migrant supporters argue the freedom of movement giving them greater security than legal residency.

Scholars continue to indicate that the free flow of workers in the home nation may be a strong safeguard for migrants to avoid hostile employers. However most migrant workers ' schemes, for example, aim to address special job shortages, meaning that most of the temporary employees will work with the contractor that has a government department approved as "essential" with migrants (McCollum and Findlay, 2015). In situations where policymakers do not explicitly decide that migrants are "required," e.g. intra-EU migration, there are usually comparatively limited numbers of migrants or with a primary goal other than jobs, such as international students and staff on holiday. 


\section{Migrant Labor Dependence}

Temporary employee ' initiatives, due to misunderstanding and dependency, appear to get bigger and continue longer than required. In developing nations, most companies do not hire transient hires. Distortion ensures that those who have access to jobs rather than businesses that only recruit ethnic employees have access to employment. Employers who employ migrants usually face minimal coverage in domestic and almost limitless stocks of extremely low-skilled staff (Martin, 2017).

Most companies hire foreign employees believe that migrants are still accessible and that recruitment options are indicative of this presumption. Farmers who rely on migrants may grow fruit trees in areas where there are few employees, argue that they would leave without migrants to select their crops and oppose attempts to minimize temporary labor supply, because that would reduce the value of their oak expenditure, because paying greater wages or purchasing machinery will increase costs and decrease income (Salahuddin and Gow, 2015; Sirkeci and Prívara, 2017). The hiring of foreign employees by some but not all companies implies that some businesses experience specific labor resources than others. It adds to economic inequalities. Jobs who rely on migration do not have to increase wages because local employees become open for international employers when they migrate through the job market, whilst other jobs adjust to changing local working conditions (Suárez-Orozco and Suárez-Orozco, 2009).

\section{Conclusion}

There are some technical problems in the analyzes of labor market consequences of immigration. When, for example, refugees mostly go to places with rapid prosperity and high competition for labor, immigration is a trigger and a product of shift in incomes and employment. This makes it impossible to establish causality. Another concern is that foreign migration to a certain region will result in certain workforce leaving the country and going to other parts of the country or abroad. In either event, the impacts on the job market in certain regions are dissipated throughout the world, rendering it more complicated to quantify accurately by local labor market analyzes.

\section{References}

[1] Alarcón, R. (2017). US Immigration policy and the mobility of Mexicans (1882-2005). Migraciones internacionales, 6(20), 185-218.

[2] Bird, G. (2018). The biopolitical economy of guest worker programs. Biopolitical Governance: Race, Gender and Economy. London: Rowman \& Littlefield, 99-120.

[3] Bloch, A., \& McKay, S. (2015). Employment, social networks and undocumented migrants: The employer perspective. Sociology, 49(1), 38-55.

[4] Clark, G. E. (2018). Coercion and contract at the margins: Deportable labor and the laws of employment termination under US capitalism (1942-2015). Law \& Social Inquiry, 43(3), 618-646.

[5] Dancygier, R. M., \& Walter, S. (2015). Globalization, labor market risks, and class cleavages.

[6] Ellermann, A., \& Gorokhovskaia, Y. (2019). The Impermanence of Permanence: The Rise of Probationary Immigration in Canada. International Migration.

[7] Filipec, O., \& Vargová, N. (2019). Perception of Migration from non-EU countries in Slovakia: The case of Nitra Region. European Journal of Transformation studies, 7(2), 165-177

[8] Gonzalez, G. G. (2015). Guest workers or colonized labor?: Mexican labor migration to the United States. Routledge.

[9] Gordon, J. (2016). Regulating the human supply chain. lowa L. Rev., 102, 445.

[10] Gröger, A., \& Zylberberg, Y. (2016). Internal labor migration as a shock coping strategy: Evidence from a typhoon. American Economic Journal: Applied Economics, 8(2), 123-53.

[11] Hosoe, N. (2018). Impact of border barriers, returning migrants, and trade diversion in Brexit: Firm exit and loss of variety. Economic Modelling, 69, 193-204.

[12] Kalleberg, A. L. (2018). Precarious lives: Job insecurity and well-being in rich democracies. John Wiley \& Sons. 
[13] Malaeb, B., \& Wahba, J. (2018, April). Impact of refugees on immigrants' labor market outcomes. In Economic Research Forum Working Paper Series No (Vol. 1194).

[14] Martin, P. (2015). Guest or temporary foreign worker programs. In Handbook of the Economics of International Migration (Vol. 1, pp. 717-773). North-Holland.

[15] Martin, P. (2017). Trump and US immigration policy. California Agriculture, 71(1), 15-17.

[16] Massey, D. S., Arango, J., Hugo, G., Kouaouci, A., \& Pellegrino, A. (1999). Worlds in Motion: Understanding International Migration at the End of the Millennium: Understanding International Migration at the End of the Millennium. Clarendon Press.

[17] McCollum, D., \& Findlay, A. (2015). 'Flexible'workers for 'flexible'jobs? The labour market function of A8 migrant labour in the UK. Work, employment and society, 29(3), 427-443.

[18] Moroşanu, L. (2016). Professional bridges: migrants' ties with natives and occupational advancement. Sociology, 50(2), 349-365.

[19] Mosley, L., \& Singer, D. A. (2015). Migration, labor, and the international political economy. Annual Review of Political Science, 18, 283-301.

[20] Nica, E. (2015). Labor Market Determinants of Migration Flows in Europe. Sustainability, 7(1), 634-647.

[21] Orrenius, P. M., \& Zavodny, M. (2015). The impact of temporary protected status on immigrants' labor market outcomes. American Economic Review, 105(5), 576-80.

[22] Přivara, A. (2019). Citizenship-for-Sale Schemes in Bulgaria, Cyprus, and Malta. Migration Letters, 16(2), 245254.

[23] Přivara, A. (2019). Food Consumption Habits and Food Security Challenges among Immigrants. Transnational Marketing Journal, 7(1), 59-72.

[24] Prívara, A. (2019). Explaining emigration patterns in Estonia, Lithuania, Slovenia and Slovakia. Geografický časopis / Geographical journal, 71 (2019), 2, 161-180.

[25] Přivara, A., \& Prívarová, M. (2019). Nexus between Climate Change, Displacement and Conflict: Afghanistan Case. Sustainability, 11(20), 5586.

[26] Príivara, A., \& Rievajová, E. (2019). Destination Marketing and Policies Attracting High-Skilled Individuals in Germany and Singapore. Transnational Marketing Journal, 7(2), 229-244.

[27] Přivara, A., Rievajová, E., \& Yüceşahin, M. M. (2019). Labour Market Disadvantages Faced by Migrant Workers from Czech Republic, Hungary, and Slovakia in Britain. Migration Letters, 16(4), 585-594.

[28] Rievajova, E., Kovarova, A., \& Prívara, A. (2018). Measuring the income and payroll tax burden with emphasis on the effective marginal tax rate. Business and Economic Horizons (BEH), 14(1232-2019-885), 1011-1026.

[29] Ruhs, M., \& Vargas-Silva, C. (2015). The labour market effects of immigration. The Migration Observatory.

[30] Ruiz, I., \& Vargas-Silva, C. (2015). The labor market impacts of forced migration. American Economic Review, 105(5), 581-86.

[31] Salahuddin, M., \& Gow, J. (2015). The relationship between economic growth and remittances in the presence of cross-sectional dependence. The Journal of Developing Areas, 207-221.

[32] Sarkar, M. (2017). Constrained labour as instituted process: Transnational contract work and circular migration in late capitalism. European Journal of Sociology/Archives Européennes de Sociologie, 58(1), 171-204.

[33] Sirkeci, I., \& Prívara, A. (2017). Cost of Sending Remittances from the UK in the Aftermath of the Financial Crisis. Remittances Review, 2(1), 47-56.

[34] Sirkeci, I., \& Přivara, A. (2017). Kurdish Studies in Russian Language: 1917-2017. Kurdish Studies, 5(2), 187198.

[35] Sirkeci, I., Cohen, J. H., \& Príivara, A. (2017). Towards a Migration Letters Index: the most influential works and authors in Migration Studies. Migration Letters, 14(3), 397-424.

[36] Sirkeci, I., Cohen, J. H., Přivara, A., \& Utku, D. E. (2018). ÇEViRi: Migration Letters Endeksi'ne Doğru: Göç Çalışmalarını En Çok Etkileyen Eserler ve Yazarlar. Göç Dergisi, 5(2), 219-244. 
[37] Suárez-Orozco, C., \& Suárez-Orozco, M. M. (2009). Children of immigration. Harvard University Press.

[38] Todaro, M. P. (1969). A model of labor migration and urban unemployment in less developed countries. The American economic review, 59(1), 138-148.

[39] Zimmermann, K. F. (2016). Refugee and migrant labor market integration: Europe in need of a new policy agenda. Unpublished manuscript, UNU-MERIT. 